\title{
On the identity and phylogenetic position of Dero indica (Clitellata: Naididae)
}

\author{
Sivabalan Srinivasan ${ }^{1}$ (D) $\cdot$ Svante Martinsson ${ }^{2}$ (D) $\cdot$ Mohammed Ibrahim Naveed $^{1}$ (i)
}

Received: 15 October 2019 / Accepted: 10 January 2020 / Published online: 20 January 2020

(C) The Author(s) 2020

\begin{abstract}
The identity and validity of the freshwater worm Dero indica (Clitellata: Naididae; Naidinae) has been debated, and it has been suggested that it is likely to be identical with $D$. digitata. In this study we combine a newly generated COI sequence of $D$. indica with available sequences from GenBank, to estimate the phylogeny of Dero using both Bayesian Inference and Maximum Likelihood. The trees show that $D$. indica is well separated from $D$. digitata, instead it is closest to $D$. vaga, but with low support. Furthermore, the analyses confirm the close relationship between Dero and Branchiodrilus found in previous studies, and indicates the presence of cryptic species in $D$. furcata and D. digitata.
\end{abstract}

Keywords DNA barcoding $\cdot$ Oligochaeta $\cdot$ India $\cdot$ COI

\section{Introduction}

The identity of the naidid worm Dero indica Naidu, 1962; pp 110-112 (Clitellata: Naididae: Naidinae) has historically been questioned. In the original description Naidu (1962) described it as being closest to Dero digitata and D. zeylanica, and in their global compendium on aquatic Oligochaeta, Brinkhurst and Jamieson (1971) regarded D. indica as most likely being identical to $D$. digitata. The ambiguity regarding $D$. indica was partly resolved by Naveed (2012) by studying several live and preserved specimens of $D$. indica, and found morphological differences. The two species of Dero differ from each other in the number of dorsal chaetae: $D$. digitata is characterized as having one hair and one needle chaeta, $D$. indica as

Sivabalan Srinivasan and Svante Martinsson contributed equally to this work.

Svante Martinsson

svante.martinsson@bioenv.gu.se

Sivabalan Srinivasan

ssivabalansrinivasan@gmail.com

Mohammed Ibrahim Naveed

naveed newcollege@ rediffmail.com

Department of Zoology, The New College, Chennai - 14, India

2 Department of Biological and Environmental Sciences, University of Gothenburg, Gothenburg, Sweden having two hair and two needle chaetae. However, so far, no genetic data from $D$. indica has been available, and the phylogenetic position is still unknown. Aulophorus Schmarda, 1861 is often treated as a junior synonym to Dero and are often synonomised, also in this study. Please note that Naidu (1962; pp 137-139) also descibed Aulophorus indicus, which becomes a junior homonym to $D$. indica when the two genera are treated as synonyms.

The aim of this study is to test if Dero indica is genetically distinct from $D$. digitata and other congenerics, as well as placing it phylogenetically. To obtain this, phylogenies were estimated, with both Bayesian Inference and Maximum Likelihood, on a dataset consisting of newly obtained COI (Cytochrome c oxidase subunit I) sequence of $D$. indica combined with available sequences of Dero spp. from GenBank.

\section{Material and methods}

A specimen of Dero indica was collected at Neithavayal Pond (Minjur), Tamil Nadu, India, $13^{\circ} 16^{\prime} 43.1904^{\prime \prime} \mathrm{N}, 80^{\circ} 15^{\prime}$ $11.7252^{\prime \prime} \mathrm{E}$ and identified using a combination of the monograph by Brinkhurst and Jamieson (1971), the work of Naidu (2005) on Indian aquatic Oligochaeta and the guide by Timm (2009). The specimen was preserved in ethanol. The DNA extraction and amplification were performed at the Biozone Lab, Chennai, following a phenol chloroform protocol (Pachamuthu et al. 2000). The standard barcoding gene COI 
(Cytochrome c oxidase subunit I) was amplified with the primer pair LCO1490 and HCO2198 (Folmer et al. 1994), using the following PCR-program: initial denaturation at $94{ }^{\circ} \mathrm{C}$ for $3 \mathrm{~min}$ followed with 32 cycles with $94{ }^{\circ} \mathrm{C}$ for $1 \mathrm{~min}, 48^{\circ} \mathrm{C}$ for $1 \mathrm{~min}$, and $72^{\circ} \mathrm{C}$ for $1 \mathrm{~min} 20 \mathrm{~s}$, and finishing with the final extension at $72{ }^{\circ} \mathrm{C}$ for $7 \mathrm{~min}$. The obtained COI sequence of $D$. indica was deposited in GenBank (accession no. MK302407).

The new COI sequence of $D$. indica was combined with all COI sequences of Dero available in GenBank (downloaded 2019-09-02), as well as a set of other representatives of Naidinae as outgroups (see Table 1 for details), in total 27 sequences, the sequences were aligned using MAFFT v7.017 (Katoh et al. 2002) as implemented in Geneious 8.1.9 (Biomatters Ltd., Auckland, New Zealand), using default settings.

Phylogenies were estimated using both Bayesian Inference in MrBayes v.3.2.6 (Ronquist et al. 2012) and Maximum likelihood (ML) using PhyML 3.0 (Guindon et al. 2010), as implemented at the Montpellier Bioinformatics platform (http://www.atgc-montpellier.fr/). For the Bayesian analysis the alignment was partitioned according to codon position, partitions were unlinked. Rate variation across sites was set to gamma distribution with a proportion of invariable sites; model jumping was implemented to integrate over substitution model space. The analyses ran for 20 million generations sampling every 10,000 generations, the first $25 \%$ were discarded as burn-in, and a majority-rule consensus tree was constructed. For the ML analysis the Smart Model Selection (Lefort et al. 2017) with Bayesian Information criterion was used for automatic model selection; Subtree Pruning and Regrafting were used for tree improvement. Branch support was calculated with the SH-like (Shimodaira-Hasegawa test-like) approximative likelihood ratio test (aLRT) (Anisimova and Gascuel 2006). The trees were rooted according to the result in Erséus et al. (2017). All trees were drawn in FigTree 1.4.2 (Rambaut 2014) and further edited in Adobe Illustrator.

Table 1 Sequences included in the phylogeny, with species, country of collection, GenBank accession numbers, and references

\begin{tabular}{|c|c|c|c|}
\hline Species & Collection country & GenBank acc. no: & Reference \\
\hline Dero indica Naidu, 1962 & India & MK302407 & This study \\
\hline D. borellii Michaelsen, 1900 & United Kingdom & KY633385 & Erséus et al. (2017) \\
\hline D. digitata (Müller, 1774) & USA & AF534835 & Bely and Wray (2004) \\
\hline D. digitata (Müller, 1774) & USA & AF534836 & Bely and Wray (2004) \\
\hline D. digitata (Müller, 1774) & Canada & MF544417 & Dewaard, J.R. (unpubl.) \\
\hline D. digitata (Müller, 1774) & Sweden & KY633397 & Erséus et al. (2017) \\
\hline D. furcata Oken, 1815 & USA & KP204260 & Zattara and Bely (2015) \\
\hline D. furcata Oken, 1815 & - & HQ691221 & Novo et al. (2011) \\
\hline D. furcata Oken, 1815 & USA & AF534837 & Erséus et al. (2017) \\
\hline D. furcata Oken, 1815 & Taiwan & KY633388 & Erséus et al. (2017) \\
\hline D. obtusa d'Udekem, 1855 & USA & AF534838 & Bely and Wray (2004) \\
\hline D. obtusa d'Udekem, 1855 & Canada & MG423030 & Dewaard, J.R. (unpubl.) \\
\hline D. superterrenus (Michaelsen, 1912) & USA & KY633389 & Erséus et al. (2017) \\
\hline D. sp1 & USA & GQ355368 & Bely and Sikes (2010) \\
\hline$D . \mathrm{sp}$ & USA & AF534840 & Bely and Wray (2004) \\
\hline D. vaga (Leidy, 1880) & USA & AF534839 & Bely and Wray (2004) \\
\hline D. vaga (Leidy, 1880) & USA & KY633412 & Erséus et al. (2017) \\
\hline Allonais gwaliorensis (Stephenson, 1920) & Cambodia & KY633391 & Erséus et al. (2017) \\
\hline Al. inaequalis (Stephenson, 1911) & Peru & KY633390 & Erséus et al. (2017) \\
\hline Amphichaeta raptisae (Chapman, 1981 & USA & GQ355365 & Bely and Sikes (2010) \\
\hline Am. sannio Kallstenius, 1892 & Sweden & KY633392 & Erséus et al. (2017) \\
\hline Branchiodrilus spM10 & India & MH744942 & Martin et al. (2018) \\
\hline B. cleistocheata Dahl, 1957 & Cameroon & MH744913 & Martin et al. (2018) \\
\hline Chaetogaster diaphanous (Gruithuisen, 1828) & USA & AF534831 & Bely and Wray (2004) \\
\hline Nais alpina Sperber, 1948 & Sweden & GU902104 & Erséus et al. (2010) \\
\hline N. barbata Müller, 1774 & Sweden & JQ519863 & Envall et al. (2012) \\
\hline N. bretscheri Michaelsen, 1899 & Switzerland & LN810267 & Vivien et al. (2015) \\
\hline
\end{tabular}




\section{Results}

The newly generated sequence of Dero indica is 507 base pairs (bp) long, and the COI alignment is $658 \mathrm{bp}$ long, whereof 272 are variable.

The Bayesian phylogenetic estimation resulted in mainly well resolved tree (Fig. 1a). However, Dero is not recovered as monophyletic, instead Dero and Branchiodrilus are found in a well-supported, but unresolved clade. This clade is a polytomy, consisting of a well-supported Branchiodrilus, and three groups of Dero. One of them consists of $D$. indica and $D$. vaga, but the sister relationship between them are unsupported. The other two groups of Dero are well supported. The first group consists of $D$. borellii, D. furcata, and $D$. superrenus, $D$. furcata forms two groups, and $D$. borellii is very close to one of them. The second group well-supported group consists of $D$. digitata, $D$. obtusa, and unidentified $D$. sp. the two $D$. sp. are both found together with one $D$. digitata, whereas the other $D$. digitata forms a separate group.

The ML phylogenetic estimation (Fig. 1b) is in most aspect similar to the Bayesian tree, Dero and Branchiodrilus form a weakly supported clade, and in contrast to the Bayesian analysis, both genera are recovered as monophyletic, the monophyly of Dero is weakly supported, whereas Branchiodrilus is strongly supported. The same three groups of Dero found recovered in the Bayesian tree are also recovered here, with the same internal relationships as in the Bayesian analysis. The support for the sister-group relationship between $D$ indica and $D$. vaga is weak.

\section{Discussion}

Both phylogenetic analyses (Fig. 1) indicated a sister-group relationship between $D$. indica and D. vaga but, the support for this relationship is weak in both trees. However, we can conclude that $D$. indica is not closely related to $D$. digitata, as they well-separated in the trees, as well as differing morphologically (Naveed 2012), also summarised in the Introduction. We only have representatives of seven of the about $35-40$ described species of Dero, and it is likely that $D$. indica is closer to some of the species not included in this study. More species need to be sequenced to find the exact position of $D$. indica.

Of the included species, two have deep divergences, indicating that there could be cryptic species involved. Furthermore, $D$. borellii is very close to one of the lineages of $D$. furcata, indicating that they could be the same species. To properly test this, more genetic markers are needed.

There are very few molecular studies on the clitellate fauna of India (Chakma et al. in press; Martin et al. 2018; see also Lalthanzara et al. 2018) and there are currently only seven
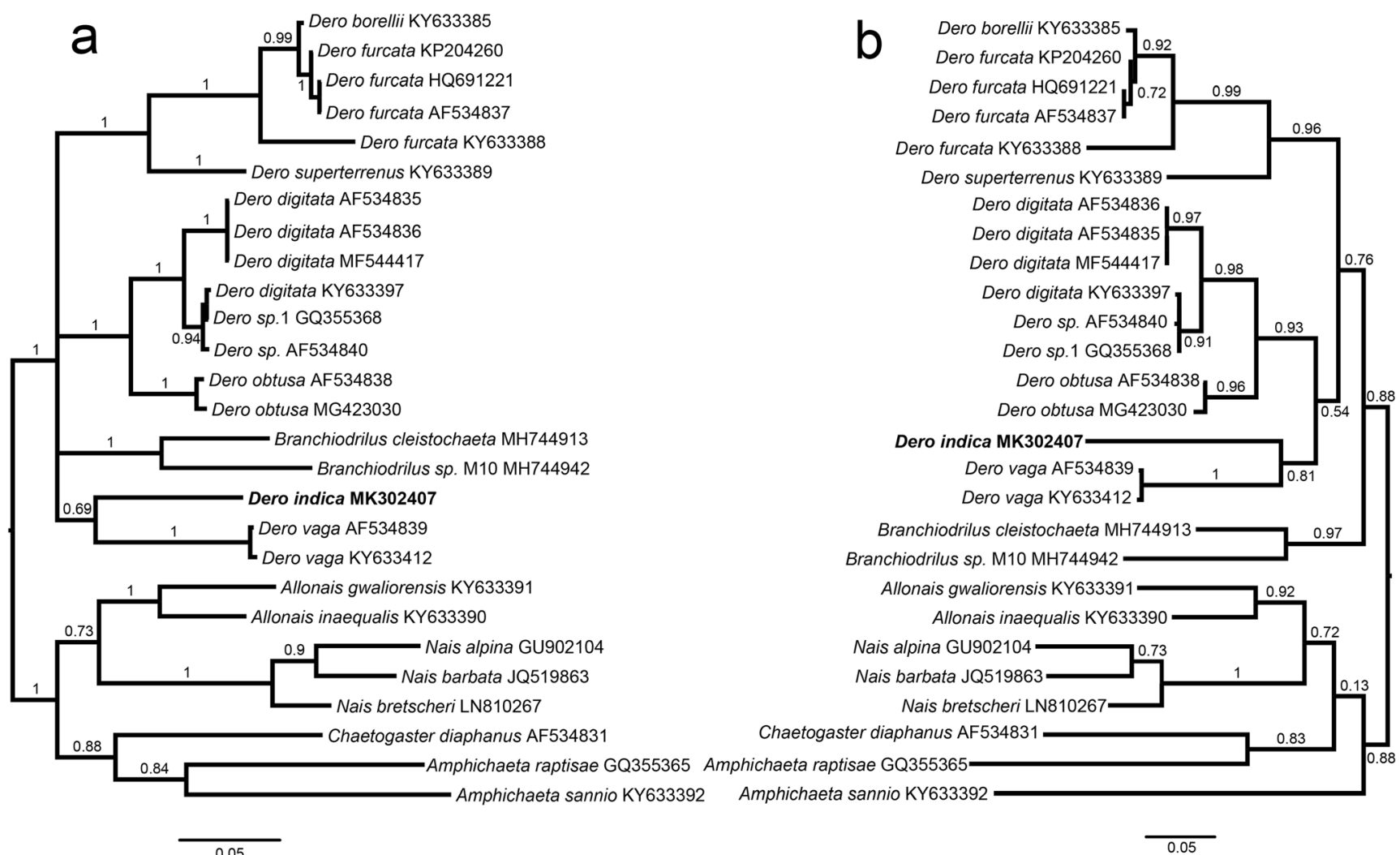

Fig. 1 COI trees of Dero. a Estimated with Bayesian Inference in MrBayes. Values at branches are posterior probabilities; $\mathbf{b}$ estimated with Maximum Likelihood in PhyML. Values at branches are SH-like aLRT support values. Scales show expected number of changes per site 
records of COI sequences from the family Naididae from India in GenBank (search performed 2019-09-13). There is great potential for the use molecular methods in the exploration of the clitellate fauna of India, and hopefully, there will be more studies in the future, characterising the clitellate fauna of India.

Acknowledgments Open access funding provided by University of Gothenburg. We are grateful to Dr. Tarmo Timm and Dr. Christer Erséus for their encouragement and support. We thank the management, Principal and Head of the Department of Zoology, The New College, Chennai for providing necessary facilities, and Biozone Lab, Chennai for the support in molecular studies.

Open Access This article is licensed under a Creative Commons Attribution 4.0 International License, which permits use, sharing, adaptation, distribution and reproduction in any medium or format, as long as you give appropriate credit to the original author(s) and the source, provide a link to the Creative Commons licence, and indicate if changes were made. The images or other third party material in this article are included in the article's Creative Commons licence, unless indicated otherwise in a credit line to the material. If material is not included in the article's Creative Commons licence and your intended use is not permitted by statutory regulation or exceeds the permitted use, you will need to obtain permission directly from the copyright holder. To view a copy of this licence, visit http://creativecommons.org/licenses/by/4.0/.

\section{References}

Anisimova M, Gascuel O (2006) Approximate likelihood-ratio test for branches: a fast, accurate, and powerful alternative. Syst Biol 55: 539-552. https://doi.org/10.1080/10635150600755453

Bely AE, Sikes JM (2010) Latent regeneration abilities persist following recent evolutionary loss in asexual annelids. Proc Natl Acad Sci USA 107:1464-1469. https://doi.org/10.1073/pnas.0907931107

Bely AE, Wray GA (2004) Molecular phylogeny of naidid worms (Annelida: Clitellata) based on cytochrome oxidase I. Mol Phylogenet Evol 30:50 63. https://doi.org/10.1016/s1055-7903(03)00180-5

Brinkhurst RO, Jamieson BGM (1971) Aquatic Oligochaeta of the world. Oliver and Boyd, Edinburgh

Chakma, S., Martinsson, S., Srinivasan, S., Ghani A.A., Adam, R., Naveed, M.I. (in press). Preliminary report on freshwater oligochaetes from some districts of Tamil Nadu (India), along with the DNA barcode sequence of a commercially important oligochaete in Chennai. https://doi.org/10.11646/zoosymposia.0.0.0

Chapman PM (1981) A new species of Homochaeta (Oligochaeta: Naididae) from the west coast of Canada. Proc Biol Soc Wash 94: 455-457

Dahl IO (1957) Results from the Danish expedition to the French Cameroons, 1949-1950. XXII Oligochaeta BIFAN 19:1154-1172

d'Udekem J (1855) Histoire naturelle du Tubifex des ruisseaux. Mem Cour Sav Etr Acad R Sci Belg 26:1-38

Envall I, Gustavsson LM, Erseus C (2012) Genetic and chaetal variation in Nais worms (Annelida, Clitellata, Naididae). Zool J Linn Soc 165:495-520. https://doi.org/10.1111/j.1096-3642.2012.00828.x

Erséus C, Rota E, Matamoros L, De Wit P (2010) Molecular phylogeny of Enchytraeidae (Annelida, Clitellata). Mol Phylogenet Evol 57: 849-858. https://doi.org/10.1016/j.ympev.2010.07.005

Erséus C, Envall I, De Wit P, Gustavsson LM (2017) Molecular data reveal a tropical freshwater origin of Naidinae (Annelida, Clitellata, Naididae). Mol Phylogenet Evol 115:115-127. https:// doi.org/10.1016/j.ympev.2017.07.016
Folmer O, Black M, Hoeh W, Lutz R, Vrijenhoek R (1994) DNA primers for amplification of mitochondrial cytochrome c oxidase subunit I from diverse metazoan invertebrates. Mol Mar Biol Biotechnol 3:294-299

Gruithuisen FVP (1828) Über die Nais diaphana und Nais diastropha mit dem Nerven-und Blutsystem derselben. Nova Acta Physico-Med 14:1-409

Guindon S, Dufayard JF, Lefort V, Anisimova M, Hordijk W, Gascuel O (2010) New algorithms and methods to estimate maximumlikelihood phylogenies: assessing the performance of PhyML 3.0. Syst Biol 59:307-321. https://oi.org/10.1093/sysbio/syq010

Kallstenius E (1892) Eine neue Art der Oligochaetengattung Amphichaeta. Biol Fören Förh 4

Katoh K, Misawa K, Kuma K, Miyata T (2002) MAFFT: a novel method for rapid multiple sequence alignment based on fast Fourier trasform. Nucleic Acids Res 30:3059-3066

Lalthanzara, H., Lalfelpuii, R., Zothansanga, C., Vabeiryureilai, M., Senthil Kumar, N., Gurusubramanium, G. (2018). Oligochaete taxonomy - The rise of earthworm DNA barcode in India. Science Vision 18:1-10.

Lefort V, Longueville J-E, Gascuel O (2017) SMS: smart model selection in PhyML. Mol Biol Evol 34:2422-2424. https://doi.org/10.1093/ molbev/msx149

Leidy J (1880) Notice of some aquatic worms of the family Naides. Am Nat 14:421-425

Martin P, Martinsson S, Wuillot J, Erséus C (2018) Integrative species delimitation and phylogeny of the branchiate worm Branchiodrilus (Clitellata, Naididae). Zool Scr 47:727-742. https://doi.org/10. 1111/zsc. 12316

Michaelsen W (1899) Beiträge zur Kenntniss der Oligochäten. Zool Jahrb Abt Anat Ontog Tiere 12:105-144

Michaelsen W (1900) Oligochaeta. vol 10. Das Tierreich - Eine Zusammenstellung und Kennzeichnung der rezenten Tierformen. Friedländer \& Sohn, Berlin. https://doi.org/10.5962/bhl.title.1108

Michaelsen W (1912) Über einige zentralamerikanische Oligochäten. Arch Naturgesch 78:112-129

Müller OF (1774) Vermium terrestrium et fluviatilium, seu animalium infusoriorum, helminthicorum et testaceorum, non marinorum, succincta historia, vol 1. Heineck \& Faber, Kopenhagen and Leipzig

Naidu KV (1962) Studies on the freshwater Oligochaeta of South India I. Aeolosomatidae and Naididae, part 3. J Bombay Nat Hist Soc 59:520-546

Naidu KV (2005) The Fauna of India and the adjacent countries-aquatic Oligochaeta. Zoological Survey of India, Kolkata

Naveed MI (2012) Preliminary studies on aquatic Oligochaeta in and around Chennai, Tamil Nadu, India. Turk J Zool 36:25-37. https:// doi.org/10.3906/zoo-1002-33

Novo M, Almodovar A, Fernandez R, Giribet G, Diaz Cosin DJ (2011) Understanding the biogeography of a group of earthworms in the Mediterranean basin - the phylogenetic puzzle of Hormogastridae (Clitellata: Oligochaeta). Mol Phylogenet Evol 61:125-135. https:// doi.org/10.1016/j.ympev.2011.05.018

Oken L (1815) Lehrbuch der Naturgeschichte. Dritter Theil, Zoologie. Erste Abteilung, Fleischlose Thiere. Jena, Germany

Pachamuthu P, Kamble ST, Clark TL, Foster JE (2000) Differentiation of three phenotypically similar Blattella $\mathrm{spp} .:$ analysis with polymerase chain reaction-restriction fragment length polymorphism of mitochondrial DNA. Ann Entomol Soc Am 93:1138-1146. https://doi. org/10.1603/0013-8746(2000)093[1138:DOTPSB]2.0.CO;2

Rambaut A (2014) FigTree v1.4.2. A graphical viewer of phylogenetic trees. http://ree.bio.ed.ac.uk/software/figtree/ (accessed January 2019)

Ronquist F, Teslenko M, van der Mark P, Ayres DL, Darling A, Hohna S, Larget B, Liu L, Suchard MA, Huelsenbeck JP (2012) MrBayes 3.2: efficient Bayesian phylogenetic inference and model choice across a large model space. Syst Biol 61:539-542. https://doi.org/10.1093/sysbio/sys029 
Schmarda, L. (1861). Neue wirbellose Thiere beobachtet und gesammelt auf einer Reise um die Erde 1853 bis 1857 I, Turbellarien. Rotatorien und Anneliden. Part 2. 163 pp, Leipzig

Sperber C (1948) A taxonomical study of the Naididae. Zoologiska Bidrag från Uppsala 28:1-296

Stephenson J (1911) On some aquatic Oligochaeta in the collection of the Indian museum. Rec Indian Museum 6:203-214

Stephenson J (1920) On a collection of Oligochaeta from the lesser known parts of India and from eastern Persia. Mem Indian Museum 7:191-261

Timm T (2009) A guide to the freshwater Oligochaeta and Polychaeta of northern and Central Europe. Lauterbornia 66:1-235
Vivien R, Wyler S, Lafont M, Pawlowski J (2015) Molecular barcoding of aquatic oligochaetes: implications for biomonitoring. PLoS One 10:e125485. https://doi.org/10.1371/journal.pone.0125485

Zattara EE, Bely AE (2015) Fine taxonomic sampling of nervous systems within Naididae (Annelida: Clitellata) reveals evolutionary lability and revised homologies of annelid neural components. Front Zool 12:8. https://doi.org/10.1186/s12983-015-0100-6

Publisher's note Springer Nature remains neutral with regard to jurisdictional claims in published maps and institutional affiliations. 